\title{
PENGUATAN PROMOSI DESA WISATA BERBASIS KEARIFAN DI DESA PUJON KABUPATEN MALANG
}

\author{
Anak Agung Sagung Alit Widyastuty ${ }^{1)}$, Siti Nuurlaily Rukmana ${ }^{2)}$, Annisa Budhiyani Tribhuwaneswari ${ }^{3)}$ \\ 1,2,3 Fakultas Teknik Universitas PGRI Adi Buana Surabaya \\ Email: ${ }^{1}$ sagungalit@unipasby.ac.id, ${ }^{2}$ nuurlaily_rukmana@unipasby.ac.id, 3annisatb@unipasby.ac.id
}

\begin{abstract}
Abstrak
Desa wisata sebagaian besar berbasis pada kearifan lokal desa adalah bentuk kegiatan terintegrasi antara atraksi, akomodasi, fasilitas pendukung dan fasilitas tambahan berupa manajemen desa yang disajikan dalam struktur kehidupan masyarakat yang terikat dengan prosedur tradisi dan norma yang berlaku di desa. Pengembangan desa wisata yang berkelanjutan membutuhkan partisipasi masyarakat lokal dalam seluruh fase pengembangan mulai dari tahap perencanaan, implementasi dan pengawasan serta pengendalian. Desa Pujon Kidul di Kecamatan Pujon Kabupaten Malang merupakan salah satu desa wisata yang dikembangkan oleh masyarakat desa, memiliki potensi wisata dari sector pertanian, peternakan dan industry kecil ke menengah yang didukung kondisi geografi dan klimatologi wilayahnya. Tujuan dari kegiatan ini adalah penguatan promosi desa wisata yang berbasis kearifan lokal dengan mengidentifikasi potensi kawasan wisata desa Pujon Kidul. Pendekatan - pendekatan pelaksanaan pengabdian dengan menggunakan metode Rural Appraisal Approach (RAA) melalui Forum Group Diskusi (FGD) antara aparatur desa Pujon Kidul, Kelompok Sadar Wisata (pokdarwis) dan perwakilan masyakat desa. Hasil dari kegiatan ini adalah penguatan promosi melalui katalog potensi desa wisata dan pemahaman aparatur desa, masyarakat dan pihak swasta dalam perencanaan pengembangan desa wisata melalui pemanfaatan potensi geografi, pertanian, peternakan dan perkebunan di desa wisata Pujon Kidul Kecamatan Pujon Kabupaten Malang. Kegiatan ini diakhiri dengan monev guna mengevalusi kegiatan tersebut. Hasil monev ini masyarakat mengalami peningkatan terkait desa wisata tematik, yaitu 32\% (sebelum sosialisasi) menjadi 96\% (sesudah sosialisasi).
\end{abstract}

Kata kunci : Desa Wisata, Potensi wisata, Kearifan Lokal.

\begin{abstract}
Tourism village is largely based in local wisdom is a form of integrated activities between attractions, accommodation, supporting facilities and additional facilities in the form of village management presented in the structure of community life that is bound by traditional procedures and norms that apply in the village. The development of sustainable tourism villages reguires the participation of local communities in all phases of development starting from the planning, implementation and supervision and control stages. Pujon Kidul Village in Pujon subdistrict, Malang regency is one of the tourist villages developed by the village community, which has tourism potential from the agriculture, livestock and small to mediun industries which is supported by the geographical and climatological conditions of the region. The purpose of this activity is to strengthen the promotion of village teourism based in local wisdom by identifying the potential of the Pujon Kidul village tourism area. Approach to the implementation of community service using the Rural Appraisal Approach (RAA) through a Group Discussion Forum (FGD) between the Pujon Kidul village apparatus, the Tourism Awarness Group (Pokdarwis) and the representatives of the village community. The results of this activity are strengthening promotion through a catalog
\end{abstract}


of tourism village potentials and understanding of village afficials, the community and the private sector in planning the development of tourism villages through the utilization of the potential of geography, agriculture, animal husbandry and plantations in the tourism village of Pujon Kidul District of Pujon Malang Regency. This activity is ended with monitoring and evaluate the activity. The result shows the increasing knowledge in term of thematic tourist village such as $32 \%$ (before) towards $96 \%$ (after)

Keyword : Local Wisdom, Tourism Potentials, Tourism Village

\section{PENDAHULUAN}

Kecamatan Pujon secara astronomis terletak pada $112,26^{\circ}-122,299^{\circ}$ BT dan $7,52^{\circ}-7,49^{\circ}$ LS. Luas kecamatan Pujon sebesar $130,75 \mathrm{~km}^{2}$ atau sekitar $4,39 \%$ dari luas kecamatan Malang. Secara geografis batas kecamatan Pujo berbatasan langsung dengan kabupaten Mojokerto di sebelah Utara, berbatasan dengan kota Batu di sebelah Timur, berbatasan dengan kecamatan Dau dan Kabupaten Blitar di sebelah Selatan dan berbatasan dengan kecamatan Ngantang di sebelah Barat. Kecamatan Pujon terdiri dari 10 desa yaitu desa Bendosari, desa Sukomulyo, desa Pujon Kidul, desa Pandesari, desa Pujon Lor, desa Ngroto, desa Ngabab, desa Tawangsari, desa Madirejo, dan desa Wiyurejo. Desa terluas adalah desa Pujon Kidul dengan luas 27,23 $\mathrm{km}^{2}$ (21\% dari luas kecamatan Pujon) sedangkan desa terkecil adalah Desa Ngroto dengan luas 3,28 $\mathrm{km}^{2}$ (3\% dari luas kecamatan Pujon). Letak secara geografis 8 desa berada di lereng perbukitan dan 2 desa lainnya berada di lembah dengan topografi perbukitan dan dataran. Perbukitan dan gunung yang mengelilingi wilayah kecamatan Pujon antara lain : Gunung Biru (desa Wirurejo), Gunung Argowayang (desa Tawangsari), Gunung Dworowati (desa Ngabab), Gunung Kukusan, Gunung Parangklakah, Gunung Kawi (desa Pujon Kidul) Gunung Cemoro Kandang dan Gunung Anjasmoro (desa Sebaloh dan desa Coban Rondo).

Berdasarkan data di Kecamatan Pujon dalam Angka (Winanto, 2018) roda perekonomian yang ada di kecamatan Pujon bergerak di sector peternakan, pertanian, kayu, penambangan dan sebagainya. Tercatat industry kecil sebanyak 184 usaha, industry kecil ini terkategorikan kembali menjadi industry kulit, kayu, logam/logam mulia, anyaman/gerabah/keramik, kain/tenun, makanan dan lain - lain. Jumlah objek wisata di kecamatan Pujon tercatat sebanyak 7 kawasan obyek wisata, antara lain wisata pemandian, wisata agro, wana wisata candi, dan wisata alam lainnya.

Wilayah desa Pujon Kidul secara umum sangat cocok untuk lahan pertanian dan perkebunan karena secara geologis berupa lahan hitam yang tergolong tanah subur. Berdasarkan data dari desa Pujon Kidul beberapa tanaman yang cocok yaitu jagung, buah - buahan seperti Apel, Tomat dan Wortel. Hasil pertanian tersebut dapat memberikan sumber pendapatan bagi masyarakat desa Pujon Kidul dan jika di kembangkan dengan manajemen kelompok sadar wisata yang baik mengacu pada norma dan kearifan tradisional, maka desa Pujon Kidul dapat dikembangkan menjadi kawasan wisata alam dan wisata agro. Berikut ini penggunaan lahan di desa Pujon Kidul yang akan dijabarkan pada tabel 1 .

Tabel 1. Penggunaan Lahan desa Pujon Kidul

\begin{tabular}{clcc}
\multicolumn{3}{c}{ Kecamatan Pujon Kabupaten Malang } \\
\hline No. & $\begin{array}{c}\text { Jenis } \\
\text { Penggunaan } \\
\text { Lahan }\end{array}$ & $\begin{array}{c}\text { Luas } \\
\text { (ha) }\end{array}$ & $\begin{array}{c}\text { Prosentase } \\
\mathbf{( \% )}\end{array}$ \\
\hline 1 & Perumahan & 45.807 & 21 \\
2 & Sawah & 84.742 & 39 \\
3 & Lading & 87.102 & 40 \\
4 & Perkebunan & 240 & 0 \\
5 & Lapangan & 0,5 & 0 \\
6 & Jalan desa & 8 & 0 \\
7 & Hutan lindung & 227 & 0 \\
8 & Hutan & 578 & 0 \\
& produksi & & \\
\hline
\end{tabular}


Jumlah penduduk Desa Pujon Kidul tahun 2018 sebesar 4.722 jiwa, laki - laki berjumlah 2.398 jiwa sedangkan perempuan berjumlah 2.324 jiwa. Mayoritas penduduk desa bermata pencaharian di bidang pertanian (Winanto, 2019).

Banyak hal yang mengindikasikan bahwa desa Pujon Kidul cukup berpotensi untuk menjadi destinasi wisata didukung dari sector Sumber Daya Manusia (SDM) dan Sumber Daya Alam (SDA). Berdasarkan data dari Badan Pusat Statistik Kecamatan Pujon tahun 2019, desa Pujon Kidul mempunyai jumlah wisata sebanyak 2 jenis, yaitu wisata agro dan wisata alam yang ditunjang dengan adanya homestay yang merupakan fasilitas pendukung kegiatan wisata yang berjumlah 31 homestay.

Banyaknya potensi alam dan manusia sangat mendukung gerakan pariwata dengan pemanfaatan potensi dari hasil industry kecil, pertanian dan perkebunan untuk diintegrasikan dengan wisata desa tematik yang tetap memperhatikan norma dan kearifan lokal. Untuk itu perlu adanya Penguatan promosi desa wisata berbasis kearifan lokal di desa Pujon Kidul kecamatan Pujon Kabupaten Malang.

Desa wisata merupakan kawasan yang berkaitan dengan wilayah pedesaan yang memiliki karakteristik khusus atau berbagai kearifan lokal yang terintegrasi dengan baik membentuk sebuah atraksi dan didukung dengan adanya akomodasi serta fasilitas pendukung untuk menjadi daerah tujuan wisata (Fadeli \& Sutrisno, 2016)(Susanti, 2015)(Hermawan, 2016). Pengembangan pariwisata di pedesaan dipengaruhi tiga faktor, yaitu yang pertama potensi alam maupun budaya yang menjadi karakteristik atau ciri khas yang dimiliki oleh wilayah pedesaan. Masyarakat pedesaan masih menjalankan keunikan tradisi pada komunitas tersebut berupa norma adat istiadat Kedua, lingkungan fisik yang masih alami dan jauh berbagai polusi dan kegiatan modern perkotaan. Ketiga, perkembangan ekonomi yang relatif cenderung tetap dan lambat, sehingga perlu adanya pemanfaatan potensi di sector ekonomi, sosial dan budaya kearifan lokal masyarkat secara optimal dalam pengembangan pariwisata di pedesaan (Andriyani, 2017)(Dewi, Fandeli, \& Baiquni, 2013).

Kearifan lokal menurut Peraturan Menteri Pekerjaan Umum dan Perumahan Rakyat Republik Indonesia (PermenPUPR, 2016) mempunyai arti nilai niai luhur yang berlaku dalam tata kehidupan masyarakat untuk mewujudkan perumahan dan permukiman yang sehat, aman, serasi dan teratur. Kearifan lokal dalam kegiatan ini adalah suatu gagasan konseptual di dalam masyarakat yang berupa nilai, norma, kepercayaan dan aturan - aturan khusus melalui proses yang berulang - ulang dan terinternalisasi dan interprestasi dalam suatu tradisi menjadi pedoman dalam mengatur kehidupan masyarakat (Wesnawa, 2010)(Natalia \& Widyastuty, 2015)

Desa Pujon Kidul mempunyai potensi kriteria desa wisata karena berada di lokasi geografi dan topografi yang memiliki keindahan alam, dan sumber daya alamnya berupa pertanian dan perkebunan serta kearifan lokal masyarakatnya yang ramah dan saling membantu, potensi permukiman yang sudah di manfaatkan sebagai homestay yang dapat mendampung wisatawan untuk berkunjung di desa wisata tersebut.

Penerapan strategi pemasaran yang tepat akan dapat meningkatkan animo wisatawan untuk berkunjung di tempat wisata tersebut. Hal ini dibuktikan dengan jumlah wisatawan yang meningkat $100 \%$ (Tabel 2) setiap tahunnya (Lestari \& Sunarti, 2019)..

Tabel 2. Jumlah kunjungan wisatawan desa Pujon Kidul Malang.

\begin{tabular}{|c|c|c|}
\hline No. & Tahun & Jumlah (jiwa) \\
\hline 1 & 2016 & 26.133 \\
\hline 2 & 2017 & 214.215 \\
\hline 3 & 2018 & 497.654 \\
\hline
\end{tabular}

Dalam upaya untuk mempertahankan animo pengunjung wisatawan ke desa wisata Pujon Kidul, maka perlu adanya penguatan promosi di desa wisata Pujon Kidul. Beberapa hal yang perlu diperhatikan dalam pengembangan desa wisata adalah 
pengetahuan masyarakat tentang kegiatan wisata, masyarakat harus mempunyai kesadaran dan orientasi bisnis terutama para pengelola wisata, dukungan dari aparatur dan kelembangaan, kuantitas dan kualitas dari obyek wisata, dan tentunya untuk memperkuat promosi adalah dengan adanya katalog desa wisata.

\section{METODE PELAKSANAAN}

Pelaksanaan kegiatan pengabdian secara umum terdiri dari tahapan pemanfaatan potensi hasil pertanian dan perkebunan serta sarana dan prasarana desa wisata yang diintegrasikan dengan kegiatan desa wisata tematik, kemudian dilanjutkan dengan pemaparan peta wisata .

Kegiatan ini dilaksanakan di kantor desa Pujon Kidul Kecamatan Pujon Kabupaten Malang dengan sasaran aparatur desa, pokdarwis desa dan perwakilan masyarakat (gambar 1).

Skematik rancangan pelaksanaan kegiatan pengabdian pada masyarakat dijabarkan pada gambar 2 .

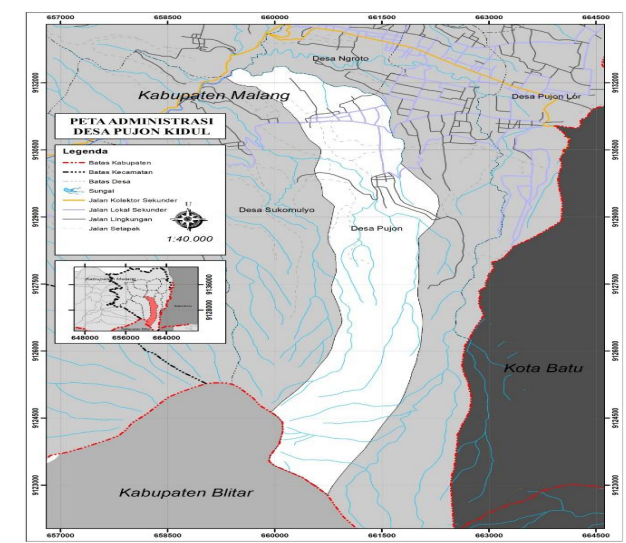

Gambar 1. Peta administrasi desa wisata Pujon Kidul

Gambaran teknologi yang akan diterapkan untuk penguatan promosi desa wisata adalah menghasilkan Katalog potensi desa Wisata Pujon Kdiul dengan mengkaji dan memetakan sebaran potensi wisata desa ke dalam sebuah katalog yan akan memudahkan wisatawan maupun penduduk desa untuk berorientasi pada sector pariwisata di desa Pujon Kidul.
Adapun prosedur pelaksanaan pengabdian ini adalah sebagai berikut :

a. Observasi lapangan dan mengadakan perjanjian serta perijinan untuk melaksanakan pengabdian di desa Pujon Kidul kecamatan Pujon Kabupaten Malang.

b. Mengidentifikasi potensi desa baik dari sarana prasarana serta potensi pertanian dan perkebunan yang dihasilkan oleh desa Pujon Kidul.

c. Melakukan pertemuan dengan sistem forum group diskusi (FGD) bersama aparatur desa, pokdarwis dan juga perwakilan masyarakat.

d. Pengolahan data hasil identifikasi potensi desa dan FGD untuk membuat katalog dan peta desa wisata.

e. Pelaksanaan sosialisasi dan penyuluhan tentang pemahaman potensi hasil pertanian dan perkebunan untuk di integrasikan dengan desa wisata tematik.

f. Monitoring dan evaluasi hasil kegiatan sosialisasi untuk mengetahui tingkat pemahaman pelaku dan pengelola desa wisata tentang penguatan promosi desa wisata tematik

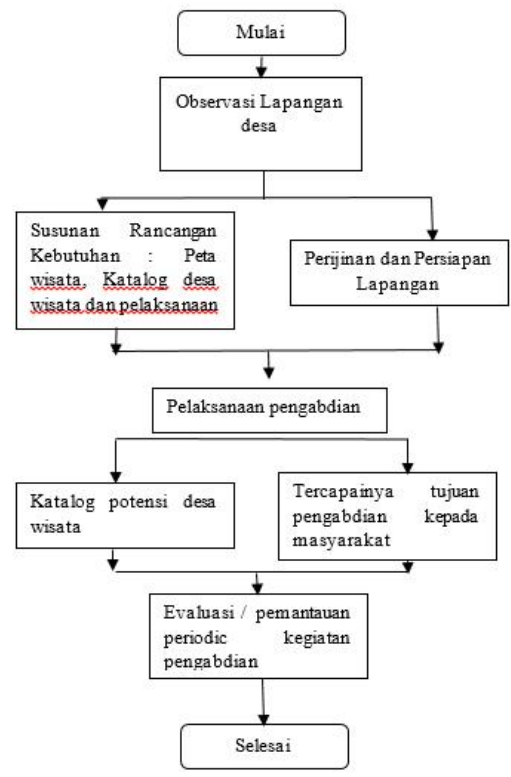

Gambar 2. Skema rancangan pelaksanaan kegiatan 
Gambaran teknologi yang akan diterapkan untuk penguatan promosi desa wisata adalah menghasilkan Katalog potensi desa Wisata Pujon Kdiul dengan mengkaji dan memetakan sebaran potensi wisata desa ke dalam sebuah katalog yan akan memudahkan wisatawan maupun penduduk desa untuk berorientasi pada sector pariwisata di desa Pujon Kidul.

Adapun prosedur pelaksanaan pengabdian ini adalah sebagai berikut :

g. Observasi lapangan dan mengadakan perjanjian serta perijinan untuk melaksanakan pengabdian

h. Mengidentifikasi potensi desa baik dari sarana prasarana serta potensi pertanian dan perkebunan yang dihasilkan

i. Melakukan pertemuan dengan sistem forum group diskusi (FGD) bersama aparatur desa, pokdarwis dan juga perwakilan masyarakat.

j. Pengolahan data hasil identifikasi potensi desa dan FGD untuk membuat katalog dan peta desa wisata.

k. Pelaksanaan sosialisasi dan penyuluhan tentang pemahaman potensi hasil pertanian dan perkebunan untuk di integrasikan dengan desa wisata tematik.

1. Monitoring dan evaluasi hasil kegiatan sosialisasi untuk mengetahui tingkat pemahaman pelaku dan pengelola desa wisata tentang penguatan promosi desa wisata tematik.

\section{HASIL DAN PEMBAHASAN}

Hasil pelaksanaan kegiatan pengabdian adalah sebagai berikut :

a. Observasi lapangan

Persiapan survey lokasi dilakukan bersama dengan tim pengabdian program studi Perencanaan Wilayah dan Kota Universitas PGRI Adi Buana Surabaya, dan hasil survey tampak potensi - potensi yang bisa dikembangkan dan di integrasikan dengan desa wisata tematik.
Lokasi obervasi dilakukan di desa Pujon Kidul dan sekitanya.

b. Identifikasi hasil observasi lapangan Identifikasi hasil lapangan berupa :

1) Potensi wilayah Beberapa dusun di desa Pujon Kidul yang mempunyai potensi wilayah yaitu

a) Dusun Maron sebagai pusat peternakan

b) Dusun Tulungrejo sebagai pusat budaya sebagai pusat permainan tradisional

c) Dusun Krajan sebagai pusat pemerintahan dan pusat wisata desa.

2) Potensi alam

Beberapa potensi alam di desa Pujon Kidul :

a) Air terjun sumber pitu Pujon

b) Coban Tunggal

c) Model Perpipaan sumber yang disebut Panasinas.

3) Potensi desa Wisata Pujon Kidul

a) Café sawah

b) Sentral PKL dan Olah - oleh

c) Guest house / homestay

d) Gazebo

e) Mushola

f) Minimarket

g) Toilet umum

h) AVT and Trail

i) Manduro

j) Parkir

k) Area tunggu

4) Potensi prasarana pendukung desa wisata pujon kidul

a) Sistem jaringan air bersih

b) Sistem telekomunikasi

c) Sistem jaringan darat

d) Sistem jaringan listrik

e) Sistem jaringan sanitasi dan air limbah

f) Sistem jaringan irigasi

g) Sistem jaringan persampahan

5) Potensi estetika kota

a) Distrik, distrik di desa Pujon Kidul adalah pertanian yang membentang di sekitaran permukiman 
b) Path, potensi path yang ada di desa Pujon Kidul sudah tersedia berupa jaringan jalan hanya masih sempit dan bisa dilalui bus ukuran kecil, mobil elf dan mobil pribadi.

c) Nodes, pusat kegiatan desa Pujon Kidul berada di Café Sawah.

d) Landmark, sama dengan pusat kegiatan desa, yang menjadi tetenger dari desa Pujon Kidul adalah Café Sawah.

e) Edge, desa Pujon Kidul wilayah hanya dibatasi dengan penanda berupa gapura masuk desa dan pembatas antar desa hanya berupa patok

6) Potensi kelembagaan desa
a) Pokdarwis (Unit wisata)
b) Bumdes Sumber Sejahtera
c) Unit Laku Pandai
d) Unit Air Bersih

c. Forum Group diskusi (FGD)

Forum group diskusi dihadiri aparatur desa, pokdarwis dan perwakilan dari masyarakat.

Hasil dari FGD ini adalah penambahan pada pola pergerakan orang, pola pergerakan barangdan sistem transportasi desa.

Masukan masukan dari hasil FGD dijadikan sebagai bahan penyempurnaan katalog desa dan pengolahan data.

d. Pengolahan data hasil identifikasi dan FGD

Hasil dari identifikasi potensi dan FGD didapatkan katalog desa wisata Pujon kidul.

Adapun beberapa bentuk katalog hasil pengolahan data yang telah disampaikan pada Gambar 3 s/d Gambar 8

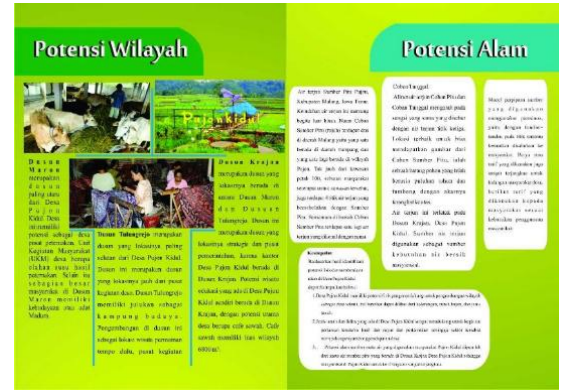

Gambar 3. Potensi wilayah dan potensi alam.

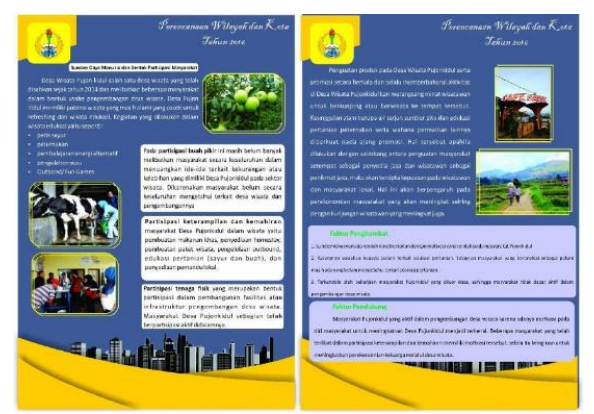

Gambar 4. Sumber daya manusia dan bentuk partisipasi masyarakat

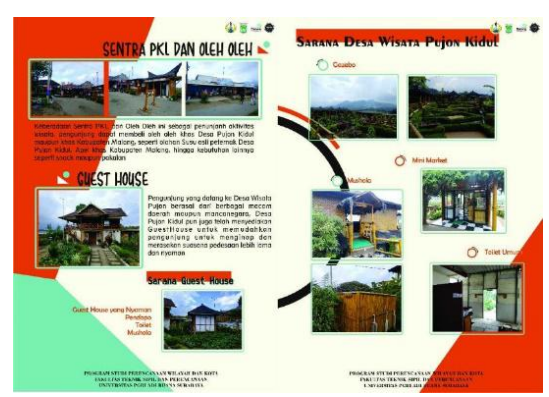

Gambar 5. Sarana desa wisata Pujon Kidul.

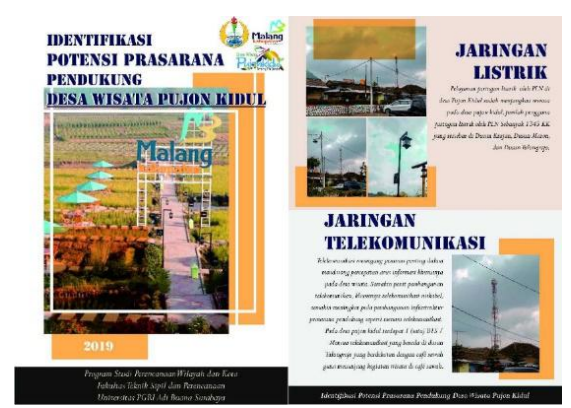

Gambar 6. Prasarana pendukung desa wisata Pujon Kidul 


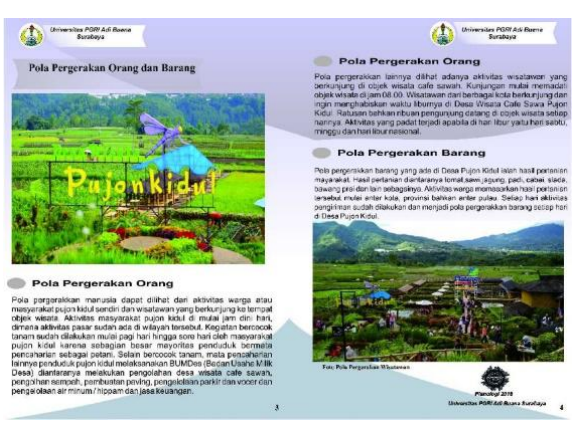

Gambar 7. Pola pergerakan orang dan barang

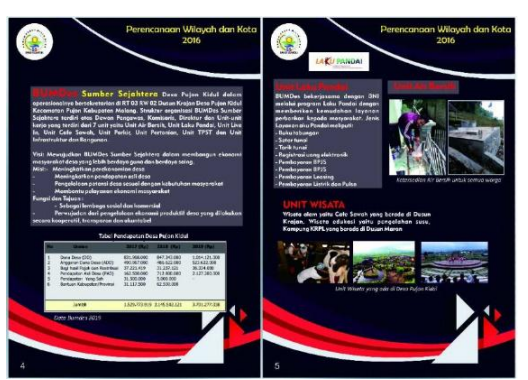

Gambar 8. Kelembagaan desa

e. Sosialisasi hasil identifikasi

Acara sosialisasi diawali dengan sambutan kepala desa Pujon Kidul, bapak Udi Hartoko dan dilanjutkan presentasi hasil pengolahan data dan hasil FGD yang berupa katalog desa. Setelah dilakukan sosialiasi dan pemahaman tentang penguatan promosi desa wisata tematik dilanjutkan dengan penyerahan buku katalog desa wisata (gambar 9, dan gambar 10).

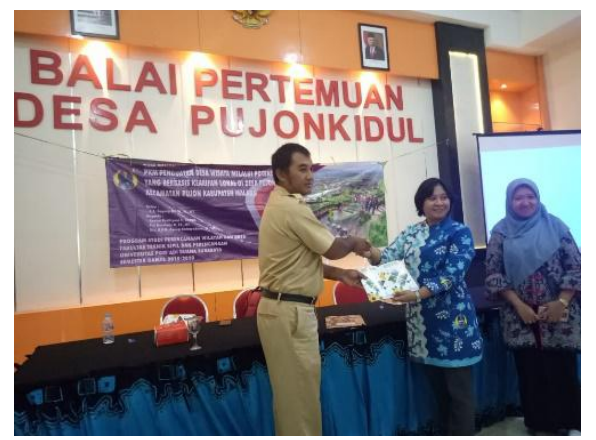

Gambar 9. Penyerahan buku katalog desa wisata

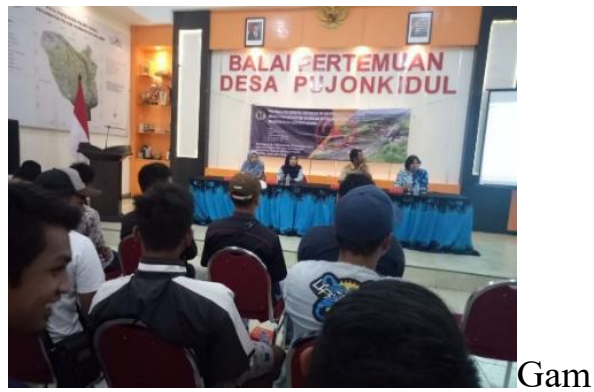

bar 10. Sosialisasi hasil pengolahan data dan penyuluhan

f. Kegiatan MONEV

Pelaksanaan MONEV ini dengan tema penguatan promosi desa wiata dilakukan setelah dua minggu pelaksanaan sosialisasi dan penyuluhan di desa Pujon Kidul. Monitoring dilakukan dengan cara meninjau langsung dan mengadakan monitoring pengetahuan aparatur desa, pokdarwis dan perwakilan dari masyarakat. Hasil monitoring dan evaluasi yang dinilai sebelum sosialisasi dan sesudah sosialisasi. Hasil dari monitoring ini mengalami peningkatan yaitu pada awal sebelum sosialisasi pengetahuan desa wisata tematik, masyarakat yang paham akan desa wisata tematik sebesar $32 \%$, tetapi setelah dilakukan sosialisasi dan penyuluhan meningkat menjadi $96 \%$. Hal ini menunjukkan bahwa masyarakat sudah mulai perduli dan memahami penguatan promosi desa wisata tematik.

\section{KESIMPULAN}

Pelaksanaan pengabdian berupa Penguatan Promosi Desa Wisata Berbasis Kearifan di desa Pujon Kabupaten Malang khususnya di desa wisata Pujon Kidul berjalan dengan baik. Hasil yang diperoleh dari pelaksanaan ini adalah penguatan potensi desa dengan tetap menjaga kearifan lokal untuk meningkatkan perekonomian masyarakat. Warga sudah bisa menikmati hasil dari pengembangan potensi sumber daya desa dan menambah pengetahuan tentang desa wisata tematik dari $32 \%$ 
menjadi $96 \%$ paham akan sistem Kelola desa wisata tematik.

\section{UCAPAN TERIMA KASIH}

Terima kasih kepada aparatur desa, pokdarwis dan masyarakat desa wisata Pujon Kidul yang telah menerima dan membantu terlaksananya kegiatan pengabdian sehingga bisa terlaksana dengan baik dan lancar. Kepada Universitas PGRI Adi Buana Surabaya melalui Lembaga Penelitian dan Pengabdian Pada Masyarakat yang memberikan dukungan berupa dana pengabdian sehingga dapat melaksanakan kegiatan pengabdian kepada masyarakat dengan baik.

\section{REFERENSI}

Andriyani, A. A. I. (2017). Pemberdayaan Masyarakat melalui Pengembangan Desa Wisata dan Implikasinya terhadap Ketahanan Sosial Budaya (Studi di Desa Wisata Penglipuran Bali). Ketahanan Nasional, 23(1), 1-16.

Dewi, M. H. U., Fandeli, C., \& Baiquni, M. (2013). Pengembangan Desa Wisata Berbasis Partisipasi Masyarakat Lokal di Desa Wisata Jatiluwih Tabanan, Bali. Kawistara, 3(2), 129-139. https://doi.org/https://doi.org/10.22146/k awistara.3976

Fadeli, M., \& Sutrisno, H. (2016). IbM Desa Wisata di Pacet-Mojokerto. In Seminar Nasional dan Gelar Produk (pp. 495507). Malang: Unviersitas Muhammadiyah malang.

Hermawan, H. (2016). Dampak pengembangan desa wisata nglanggeran terhadap ekonomi masyarakat lokal. Jurnal Pariwisata, III(2), 105-117. Retrieved from http://ejournal.bsi.ac.id/ejurnal/index.ph $\mathrm{p} / \mathrm{jp} /$ article/view/1383
Lestari, F. D., \& Sunarti. (2019). Pengaruh Motivasi Terhadap Keputusan Berkunjung (Survei Pada Pengunjung Desa Wisata Pujon Kidul Kabupaten Malang). Jurnal Administrasi Bisnis (JAB), 70(1). Retrieved from http://administrasibisnis.studentjournal.u b.ac.id/index.php/jab/article/viewFile/28 $11 / 3197$

Natalia, M., \& Widyastuty, A. A. S. A. (2015). Pengembangan Teluk Triton Berdasarkan Kearifan Lokal di Kabupaten Kaimana Papua Barat. In I. G. P. A. Putra, I. M. G. Sudharsana, \& I. N. Sukamara (Eds.), Seminar Nasional Tata Ruang dan Space \#2 Memastikan Penataan Ruang untuk Pembangunan Yang Berkelanjutan: Kearifan Lokal dan Budaya Dalam Penataan Ruang (pp. 378-390). Denpasar Bali: Program Studi Perencanaan Wilayah dan Kota Universitas Hindu Indonesia Denpasar Bali.

PermenPUPR. (2016). Peraturan Menteri Pekerjaan Umum dan Perumahan Rakyat Nomor 02 Tahun 2016 tentang Kualitas Terhadap Perumahan Kumuh dan Permukiman Kumuh (No. 02/PRT/M/2016). Jakarta, Indonesia.

Susanti, A. D. (2015). Pola Partisipasi Warga dalam Pengembangan Desa Wisata Umbul Sidomukti Kabupaten Semarang. Jurnal Modul, 15(1 (Januari-Juni)), 4756.

Wesnawa, I. G. A. (2010). Dinamika Pemanfaatan Ruang Berbasis Kearifan Lokal Di Kabupaten Buleleng Provinsi Bali. Forum Geografi, 24(1), 1-11.

Winanto, Y. C. (2018). Kecamatan Pujon Dalam Angka 2018. Malang.

Winanto, Y. C. (2019). Kecamatan Pujon Dalam Angka 2019. Malang. 